\title{
Parametric Study of G+4 Storey Structure with Vertical Geometric Irregularity Subjected to Seismic Actions \\ ${ }^{*}{ }^{1}$ Hariom Khungar, ${ }^{2}$ Pratik Vyas, ${ }^{3}$ Dr. Sharda Siddh \\ ${ }^{1,3}$ Shri Ramdeobaba College of Engineering and Management, Nagpur \\ ${ }^{2}$ Bajaj Institute of Technology,Wardha \\ Email: ${ }^{1}$ khungarhp@rknec.edu, ${ }^{2}$ vyasp63@gmail.com, ${ }^{3}$ siddhs@rknec.edu
}

Received: 06th November 2019, Accepted: 20th November 2019, Published: 31st December 2019

\begin{abstract}
The high rise structures are setting a trend day in and day out. Today in this era, people are fighting for building up the "tallest" high rise structure and in this fight the role of the structural design engineers comes. The scope of the paper is to understand and analyse the behaviour of high rise structures subjected to "vertical geometric irregularity". Out of the methods prescribed by IS 1893 (Part1):2002, ESA and RSA for G+4 in all four zones with regular and irregular configurations have been taken up. To take different models in four zones was to reduce the level of inaccuracy in results. The irregularity has been adopted at all the four floors. Only linear analysis has been performed as per IS 1893 .

A through study has been presented and results of comparison with regular structures have been presented. For the analysis SAP2000 v14.2.4 had been used. The scope of the paper also includes the evaluation of response of structures subjected to different seismic zones having low to very severe seismic intensity.
\end{abstract}

\section{Keywords}

Structures, Irregularities, Vertical Geometric Irregularity, Seismic, Storey Drift, Bending Moments and Shear Forces, Regular Configuration, Irregular Configuration

\section{Introduction}

An earthquake is a sudden and transient motion of the earth's surface. According to geologists, the earth has suffered earthquakes for hundreds of millions of years, even before humans came into existence. Because of the randomness, the lack of visible causes, and their power of destructiveness, ancient civilizations believed earthquakes to be supernatural phenomena - the curse of God. In terms of the geological time scale, it is only recently (the middle of seventeenth century) that an earthquake has been viewed as a natural phenomenon driven by the processes of the earth as a planet. Thus subsequent work, especially in nineteenth century, led to tremendous progress on the instrumental side for the measurement of earthquake data.[1,13]

Seismological data from many earthquakes were collected and analyzed to map and understand the phenomena of earthquakes. Both seismologists and earthquake engineers use the seismological data for the understanding of an earthquake and its effects, but their aims are different. Seismologists focus their attention on the global issues of earthquakes and are more concerned with the geological aspects, including the prediction of earthquakes. Earthquake engineers, on the other hand, are concerned mainly with the local effects of earthquakes, which are capable of causing significant damage to structures. They transform seismological data into a form which is more appropriate for the prediction of damage to structures or, alternatively, the safe design of structures. $[12,13,4]$

Response spectrum analysis (RSA) is a method widely used for the design of buildings. Conceptually the method is a simplification of modal analysis, i.e., response history (or time history) analysis (RHA) using modal decomposition, that benefits from the properties of the response spectrum concept. The purpose of the method is to provide quick estimates of the peak response without the need to carry out response history analysis. This is very important because response spectrum analysis (RSA) is based on a series of quick and simple calculations, while time history analysis requires the solution of the differential equation of motion over time. Despite its approximate nature, the method is very useful since it allows the use of response spectrum, a very convenient way to describe seismic hazard. RSA is very appealing to practicing engineers because seismic loading is defined by means of a response spectrum.

\section{Methodology and Formulation}

A total of 16 models were prepared on SAP2000 v14.2.4 along with all the ESA calculations as per IS 1893(Part 1):2002. The models included both regular as well as irregular configurations, in all the zones. The irregularity considered is "Vertical Geometric Irregularity" confirming to IS 1893(Part 1):2002. In each Zone there are total 4 models ,4 regular configuration models i.e.for G+4 storey and1 regular model (for each zone). Like this for total of 4 zones there are $4 \mathrm{X} 4=16$ models which were prepared and analysed on Finite Element Software (SAP 2000 v 14.2.4) and their ESA \& RSA and analysis results were obtained. 
RC Frame Building

A ground plus four stories regular RC office building of plan dimensions $19 \mathrm{~m} \mathrm{X} 10 \mathrm{~m}$ located in seismic zone $\mathrm{V}$ on medium soil is considered. Seismic analysis is performed using the Equivalent Static Analysis Method and Response Spectrum Analysis Method.

\section{Preliminary Data}

Plan of the building and sectional elevations of different RC frames are shown in figure 1 . The size of the beams and columns are given in the table 6.1 and other relevant data for analysis is shown in tables below.
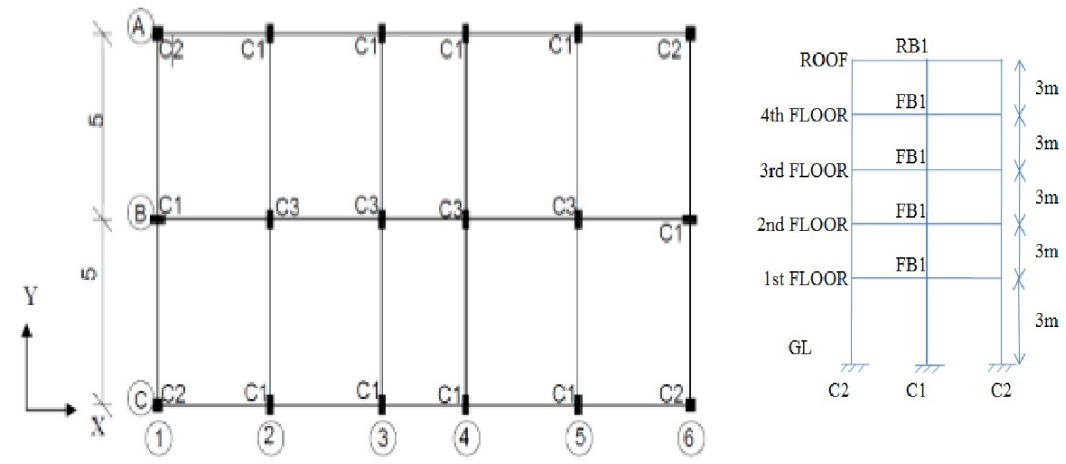

Fig 1: Plan \& Elevation of Building (All Dimensions in m) (Kumbhar O. and Kumar R.)

\begin{tabular}{|l|l|}
\hline \multicolumn{1}{|c|}{ Column (mm) } & \multicolumn{1}{c|}{ Beam (mm) } \\
\hline C1: 300 X 500 & RB1,FB1: 300 X 600 \\
\hline C2: 400 X 400 & RB2,FB2 300 X 500 \\
\hline C3: 400 X 500 & SLAB THICKNESS : 125 \\
\hline
\end{tabular}

Table 1: Table showing Dimensions of Columns and Beams

\begin{tabular}{|c|l|l|}
\hline Sr. No. & General Data & Value \\
\hline 1 & Grade of concrete & M20 \\
\hline 2 & Grade of steel & Fe 415 \\
\hline 3 & Live load on roof & $1.5 \mathrm{kN} / \mathrm{m}^{2}($ Nil for EQ) \\
\hline 4 & Live load on floors & $3 \mathrm{kN} / \mathrm{m}^{2}(25 \%$ for EQ) \\
\hline 5 & Roof finish & $1 \mathrm{kN} / \mathrm{m}^{2}$ \\
\hline 6 & Floor finish & $1 \mathrm{kN} / \mathrm{m}^{2}$ \\
\hline 7 & Brick wall on internal beams & $150 \mathrm{~mm}$ thick \\
\hline 8 & Density of concrete & $25 \mathrm{kN} / \mathrm{m}^{3}$ \\
\hline 9 & Density of brick wall & $20 \mathrm{kN} / \mathrm{m}^{3}$ \\
\hline
\end{tabular}

Table 2: Table showing General Data used for Analysis

2. Theoretical Calculations For Lumped Masses As Per Is 1893 (Part 1):2002

\begin{tabular}{|l|l|l|}
\hline 1 & Dead Slab ( For $1^{\text {st }}, 2^{\text {nd }}, 3^{\text {rd }}, 4^{\text {th }}$, and Roof $)$ & $\mathbf{5 9 3 . 7 5 ~ k N ~}$ \\
\hline 2 & Dead Beam $\left(\right.$ For $1^{\text {st }}, 2^{\text {nd }}, 3^{\text {rd }}, 4^{\text {th }}$, and Roof $)$ & $\mathbf{8 3 . 7 5 ~ k N ~}$ \\
\hline 3 & Dead Column ( For $1^{\text {st }}, 2^{\text {nd }}, 3^{\text {rd }}$ and $4^{\text {th }}$ floor $)$ & $\mathbf{2 2 0 . 5 ~ k N ~}$ \\
\hline 4 & Dead Column ( For Roof $)$ & $\mathbf{1 1 0 . 2 5 ~ k N ~}$ \\
\hline 6 & Wall Load ( For $1^{\text {st }}, 2^{\text {nd }}, 3^{\text {rd }}$ and $4^{\text {th }}$ floor $)$ & $\mathbf{1 3 3 1 . 4 ~ k N ~}$ \\
\hline 7 & Wall Load ( For Roof $)$ & $\mathbf{6 6 5 . 7 ~ k N ~}$ \\
\hline 8 & Parapet Load ( For Roof $)$ & $\mathbf{4 0 0 . 2 ~ k N ~}$ \\
\hline 9 & Floor Finish ( For $1^{\text {st }}, 2^{\text {nd }}, 3^{\text {rd }}$ and $4^{\text {th }}$ floor $)$ & $\mathbf{1 9 0 ~ k N ~}$ \\
\hline 10 & Roof Treatment $($ For Roof $)$ & $\mathbf{1 9 0 ~} \mathbf{~ N ~}$ \\
\hline 11 & Live load Roof & $\mathbf{0 ~ k N ~}$ \\
\hline
\end{tabular}

Table 3: Table for Theoretical Calculations For Lumped Masses As Per Is 1893 (Part 1):2002 


\section{Determination of Fundamental Natural Period}

The approximate fundamental natural period of vibration $\left(\mathrm{T}_{\mathrm{a}}\right)$, in seconds, of a moment resisting frame building with brick infill panels may be estimated by the empirical expression as given in IS 1893 (Part I):2002

So, $\mathrm{T}_{\mathrm{a}}=\frac{0.09 h}{\sqrt{d}}$ (in our case it is with brick infill panels) [13]

Where, $\mathrm{h}=15 \mathrm{~m}$ and $\mathrm{d}=19 \mathrm{~m}$ (for $\mathrm{T}_{\mathrm{a}}$ in $\mathrm{x}$-dir) and $10 \mathrm{~m}$ (for $\mathrm{T}_{\mathrm{a}}$ in $\mathrm{y}$-dir)

4. Determination of Design Base Shear (VB) [13]

The design base shear $V_{B}$ as given by IS 1893.In order to find Design Base Shear as per IS 1893 (Part

1):2002 $V_{B}$ we need $A_{h}$ too. As per IS 1893 design horizontal acceleration is given by $A h$

Where, $\mathrm{Z}=0.36, \mathrm{I}=1, \mathrm{R}=5$ and $\frac{\mathrm{S}_{a}}{\mathrm{~g}}=2.5$. So we can get the value of $A_{\mathrm{h}}$ for $\mathrm{x}$ and $\mathrm{y}$ direction both.

\section{Vertical Distribution of Base Shear [13]}

The design base shear computed shall be distributed along the height of the building as per the expression given in IS 1893 (Part 1):2002 .So, we can calculate the values of $\mathrm{Q}_{1}, \mathrm{Q}_{2}, \mathrm{Q}_{3}, \mathrm{Q}_{4}$ and $\mathrm{Q}_{5}$.

For G+4 (Zone - V Regular Configuration)

Total Seismic Weight "W" $=14291.25 \mathrm{kN}$

\begin{tabular}{|c|c|c|c|c|c|c|c|}
\hline \multicolumn{8}{|c|}{ Base shear at different levels } \\
\hline Floor level & $\mathrm{W}_{\mathrm{i}}$ & $\mathrm{h}_{\mathrm{i}}$ & $\mathrm{Wi}(\mathrm{hi})^{2}$ & $\left(Q_{i}\right) \mathrm{x}$ & $\left(Q_{i}\right) y$ & $\begin{array}{l}\text { Cumulative } \\
\qquad\left(\mathrm{Q}_{\mathrm{i}}\right) \mathrm{x}\end{array}$ & $\begin{array}{l}\text { Cumulative } \\
\qquad\left(\mathrm{Q}_{\mathrm{i}}\right) \mathrm{y}\end{array}$ \\
\hline Roof & 2443.65 & 15 & 549821.3 & 524.023 & 524.023 & 524.023 & 524.023 \\
\hline 4 & 2961.9 & 12 & 426513.6 & 406.501 & 406.501 & 930.524 & 930.524 \\
\hline 3 & 2961.9 & 9 & 239913.9 & 228.657 & 228.657 & 1159.181 & 1159.181 \\
\hline 2 & 2961.9 & 6 & 106628.4 & 101.625 & 101.625 & 1260.806 & 1260.806 \\
\hline 1 & 2961.9 & 3 & 26657.1 & 25.4063 & 25.4063 & 1286.212 & 1286.212 \\
\hline & & इWi.hi2 & 1349534.25 & & & $\left(\mathbf{V}_{B}\right) \mathbf{x}$ & $\left(V_{\mathbf{B}}\right) \mathbf{y}$ \\
\hline & $\left(T_{a}\right) x$ & 0.30971 & & \multirow{2}{*}{\multicolumn{2}{|c|}{$\begin{array}{c}\text { Design horizontal } \\
\text { Acceleration } \\
\left(\mathrm{m} / \mathrm{sec}^{2}\right)\end{array}$}} & $\left(A_{h}\right) x$ & 0.09 \\
\hline $\begin{array}{l}\text { Funaamental } \\
\text { natural period (sec) }\end{array}$ & $\left(\mathrm{T}_{\mathrm{a}}\right) \mathrm{y}$ & 0.42691 & & & & $\left(A_{h}\right) y$ & 0.09 \\
\hline \multirow{2}{*}{$\begin{array}{l}\text { Design Seismic } \\
\text { base shear }(k N)\end{array}$} & $\left(V_{B}\right) \mathrm{x}$ & 1286.21 & & & & & \\
\hline & $\left(V_{B}\right) y$ & 1286.21 & & & & & \\
\hline
\end{tabular}

Table 4: Table showing Calculations for Analysis by Equivalent Static Lateral Force Method

Note: The values of $\left(\mathrm{Q}_{\mathrm{i}}\right) \mathrm{x}$ and $\left(\mathrm{Q}_{\mathrm{i}}\right) \mathrm{y}$ from the above table are the values of EQX and EQY respectively, which are to be applied as a nodal force in $\mathrm{X}$ and $\mathrm{Y}$ directions respectively at each floor at their centre of gravities.

\section{Analysing ESA and RSA ON SAP 2000 V14.2.4}

Analysis results in SAP2000 v14.2.4 along with all the ESA and RSA calculations as per IS 1893(Part 1):2002. The analysis results obtained were for Base Shear, Lateral Displacements, Storey Drift Ratio, Shear Forces and Bending Moments .Based on the results obtained various graphs were plotted.

1. Base Shear: Table below shows base shear at different levels for a $\mathrm{G}+4$ Zone-V having Irregular floors

\begin{tabular}{|c|c|c|c|}
\hline Floor levels & $\left(\mathrm{V}_{\mathrm{B}}\right) \mathrm{x}(\mathrm{kN})$ & Floor levels & $\left(\mathrm{V}_{\mathrm{B}}\right) \mathrm{y}(\mathrm{kN})$ \\
\hline 4 & 1137.97 & 4 & 1137.97 \\
\hline 3 & 1054.80 & 3 & 1054.80 \\
\hline 2 & 911.71 & 2 & 911.71 \\
\hline 1 & 768.63 & 1 & 768.63 \\
\hline
\end{tabular}

Table 5: Table Base Shear at Different Levels for a G+4 Zone-V having Irregular Floors 
2. Lateral Displacement for $G+4(R S A-X)$ and $G+4(R S A-Y)$

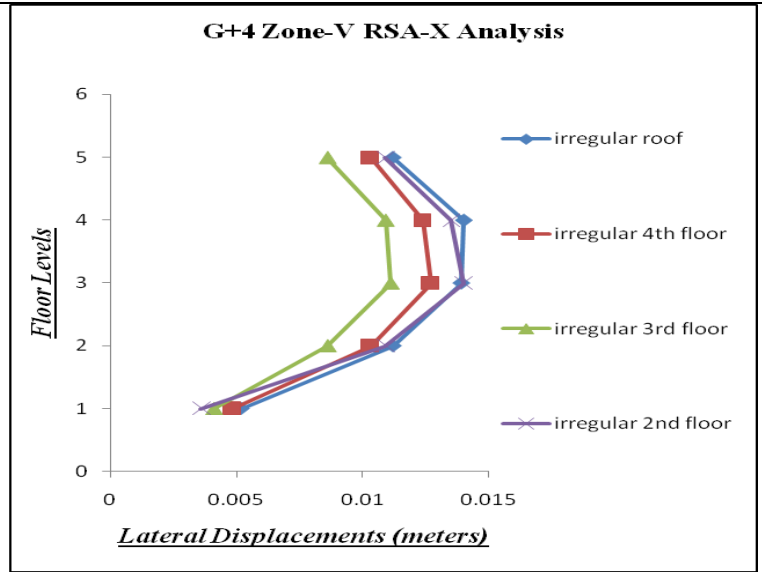

Fig 3: shows variation of Lateral Displacements at different levels for a $\mathbf{G}+4$ Zone- $V$ having Irregular floors for RSA-X

3. Storey Drift Ratio (SDR) for $G+4$

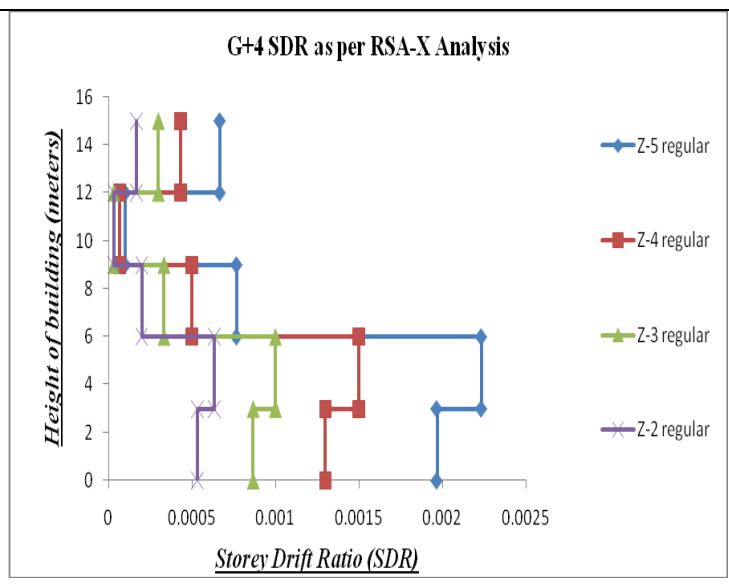

Fig 4: Variation of SDR with height of a G+4 building for RSA-X

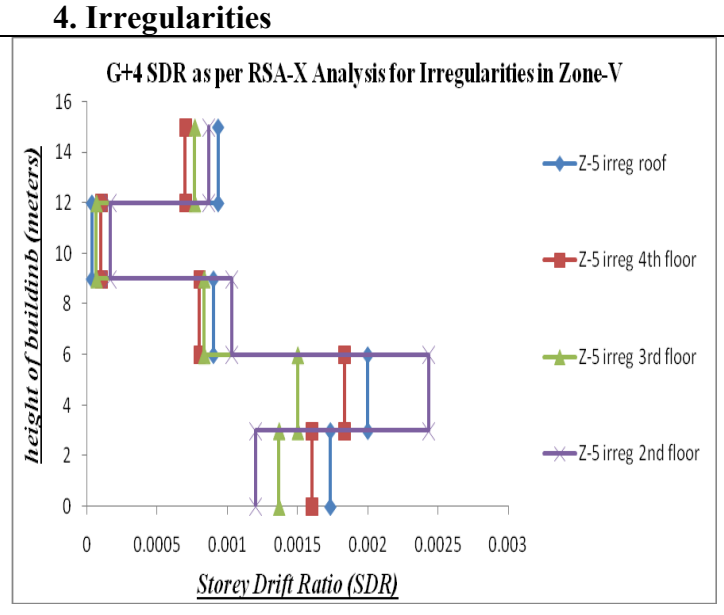

Fig 6: Variation of Storey Drift Ratio with height of a G+4 Irregular building for RSA-X in Zone -V

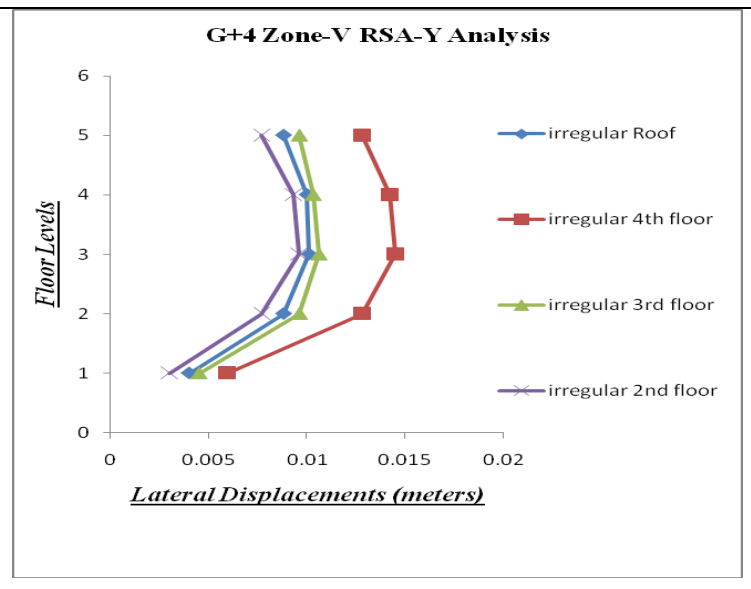

Fig 4: shows Variation of Lateral Displacements at different levels for a $\mathbf{G}+4$ Zone- $V$ having Irregular floors for RSA-Y

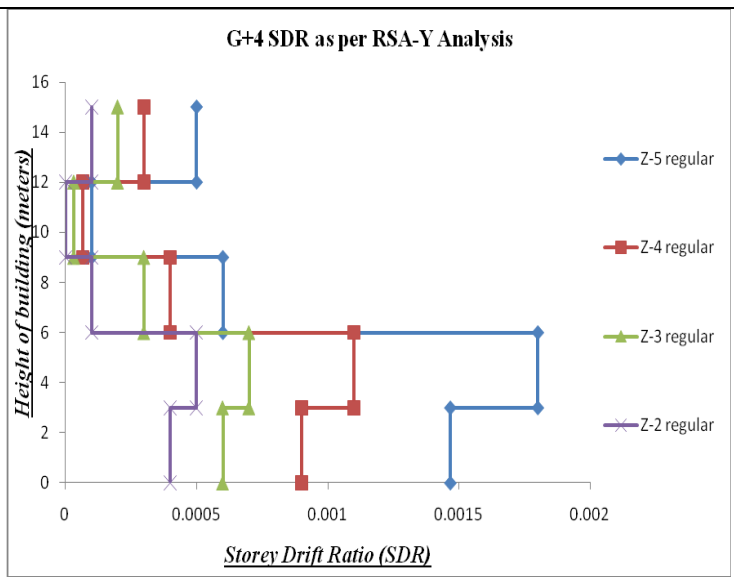

Fig 5: Variation of SDR with height of a G+4 building for RSA-Y

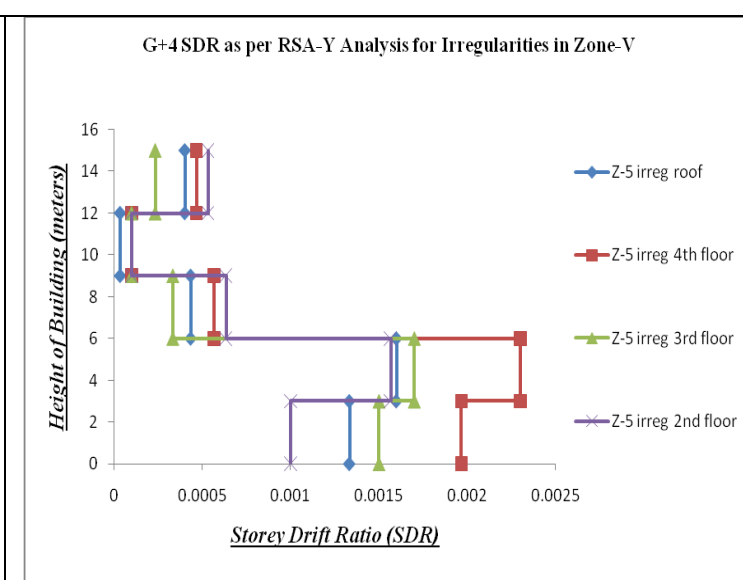

Fig 7: Variation of Storey Drift Ratio with height of a G+4 Irregular building for RSA-Y in Zone -V 


\section{Shear Force}

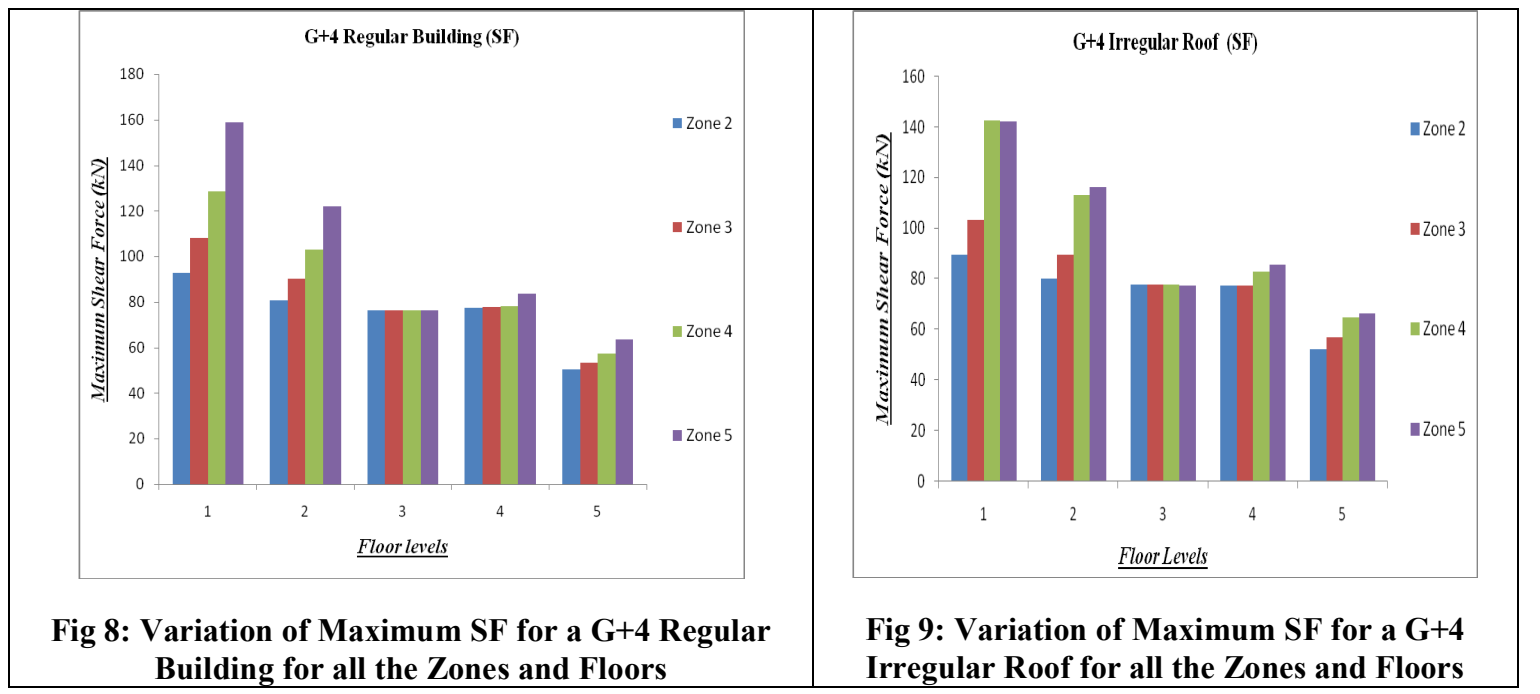

6. Bending Moment

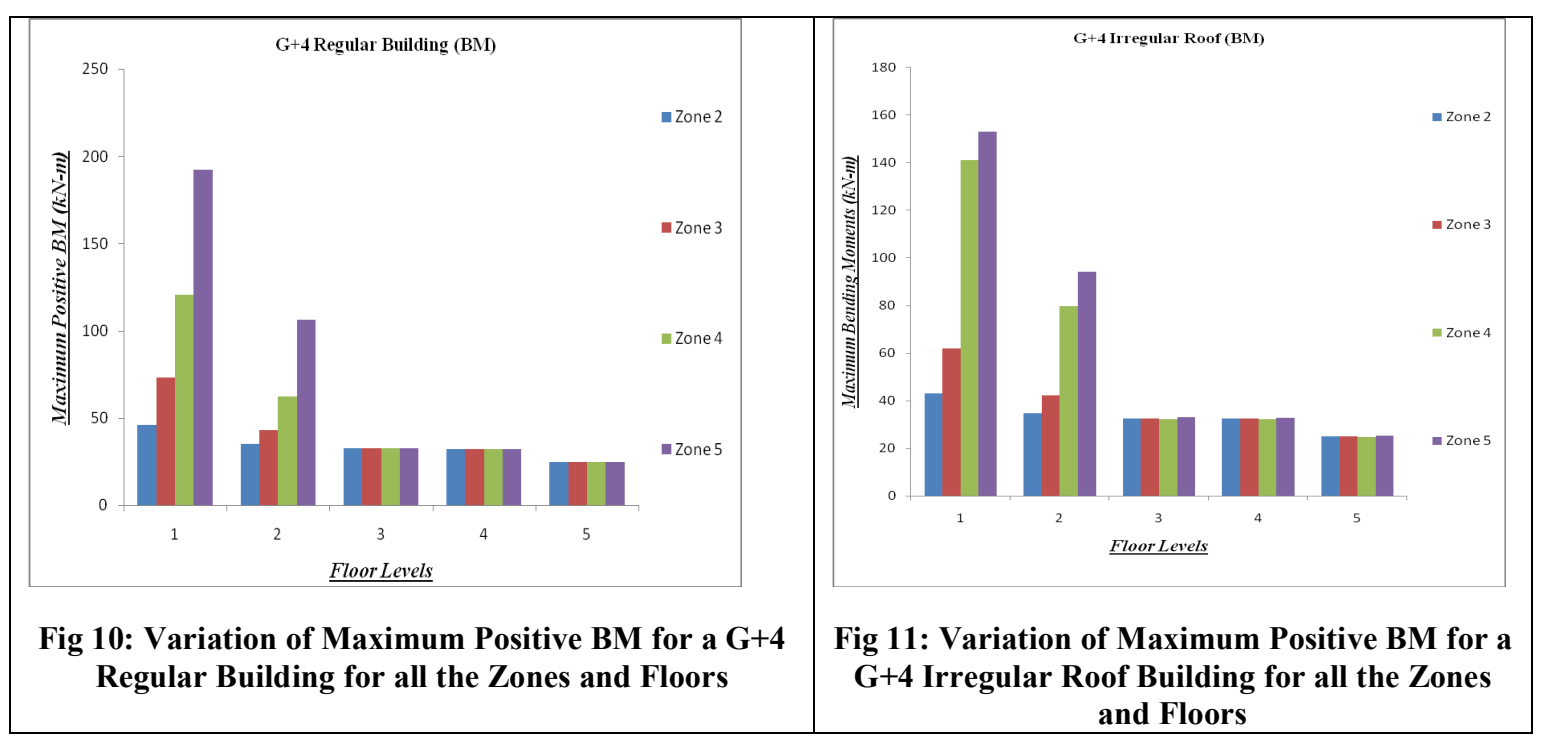

\section{Results}

a) The base shear increases with the increase in floor level of the building.

b) When the irregularity in Zone-V for a low rise building, eg. G+4 (vertical geometric) is considered at the top floor only out of all the irregular floors, such buildings show the maximum lateral displacement. But as we increase the number of stories, it can be seen that with increase in story height and considering irregularity (vertical geometric) at every floor.

c) It can be seen from the models of $\mathrm{G}+4$ regular buildings that the $\mathrm{G}+4$ regular buildings are safe in all the Zones with regards to SDR.

d) It can also be seen that the shear force and bending moments decrease with increase in floor levels for both regular as well as irregular configurations.

\section{Conclusion and Comments $[2,12,13]$}

An attempt have been made in this paper and a $\mathrm{G}+4$ storey structure in all four zones with regular and irregular configurations have been taken up. Different models in four zones were modelled to reduce the level of inaccuracy in results. Including irregularity has been adopted at all the four floors and linear analysis has been performed using SAP2000 v14.2.4 as per IS 18932002 (Part I).On evaluation of response of structures subjected to different seismic zones having low to very severe seismic intensity following concluding remarks can be made: 
a) It can be seen that the base shear in X-direction is more as compared to the base shear in $\mathrm{Y}$ direction as the building is more flexible in Y-direction.

b) The maximum lateral displacements are observed when the irregularity was considered at bottom floors only.

c) Also the maximum variation in SDR is observed as we move from the $1^{\text {st }}$ floor to $2^{\text {nd }}$ floor in all the four zones.

d) The soft stories are subjected to the maximum bending moments and shear forces. So accordingly such soft stories must be designed for additional Shear forces and Bending moments.

\section{References}

1. Chopra A.K., (2015). Dynamics of structure, Pearson, New Delhi, India.

2. Coasta G.A, Oliveira C.S., and Durate R.T. (1988). "Influence of vertical irregularities on seismic response of building".Proc., 9th world conference on earthquake engineering (WCEE-1988), Tokyo Kyoto, Japan , 491-496.

3. Damodarasamy S.R, and Kavitha S., "Book on Basics of Structural Dynamics and Aseismic Design", PHI Learning Pvt. Ltd.

4. Das S., and Nau J.M. (2003). "Seismic Design Aspects of Vertically Irregular Reinforced Concrete Buildings.” Earthquake Spectra, 19(3), 455-477.

5. Datta T.K, (2010). "Report on Seismic Analysis of Structures", John Wiley and Sons (Asia) Pvt. Ltd.

6. Fragiadakis M.,(2013) " Response Spectrum analysis of structures subjected to seismic actions" , Encyclopedia of Earthquake Engineering, Springer-Verlag Berlin Heidelberg

7. IS 1893(Part 1):(2002), "Criteria for earthquake resistant design of structures, Part 1 general provision and buildings (fifth revision), BIS, New Delhi, India."

8. Kumbhar O., and Kumar R.(2014) , "Analysis and design of R.C buildings using SAP-2000", VNIT, Nagpur,India

9. Mahesh S., Rao B.P, "Comparison of Analysis and Design of Regular and Irregular Configuration of Multistorey Building in various seismic zones and various types of soils using ETABS and STAAD", iosr journals.

10. Murti C.V.R. ,Goswami R. ,Vijayanarayanan A,R. and Mehta V.V.(2012), some concepts in earthquake behaviour of buildings Gujarat State Disaster Management Authority (GSDMA).

11. Soni,D.P.,and Misrty,B.B.,(2006)."Qualitative review of seismic response of vertically irregular building frame"J. of earthquake technology, technical note.,vol.43(4),121-132.

12. Wong, C.M. and Tso, W.K. (1994). "Seismic Loading for Buildings with Setbacks", Canadian Journal of Civil Engineering, 21(5), 863-871 